\title{
Geochemical Studies of Setiu Lagoon, Terengganu, Malaysia
}

\author{
Ong, M.C. ${ }^{1 *}$, Kamaruzzaman, B.Y. ${ }^{2}$ and Joseph, B. ${ }^{3}$ \\ ${ }^{1}$ Deparment of Marine Sciences, Faculty of Maritime Studies and Marine Science, University Malaysia \\ Terengganu, 21030 Kuala Terengganu*ong@umt.edu.my (Corresponding author) \\ ${ }^{2}$ Institute of Oceanography and Maritime Studies, International Islamic University Malaysia, Bandar Indera \\ Mahkota, 25200 Kuantan, Pahang \\ ${ }^{3}$ Institute of Oceanography, University Malaysia Terengganu, 21030 Kuala Terengganu \\ Received in $15^{\text {th }}$ September 2008, accepted in revised form $14^{\text {th }}$ December 2008.
}

\begin{abstract}
Setiu lagoon were collected in order to analyze the heavy metals concentrations using the sensitive Inductively Coupled Plasma Mass Spectrometer (ICP-MS). Results from this study revealed that the average sediment concentration of lead $(\mathrm{Pb})$, cobalt $(\mathrm{Co})$ and copper $(\mathrm{Cu})$ were $23.26 \mu \mathrm{g} / \mathrm{g}$ dry weight, $22.29 \mu \mathrm{g} / \mathrm{g}$ dry weight and $47.25 \mu \mathrm{g} / \mathrm{g}$ dry weight, respectively. The calculated enrichment factors $(\mathrm{EF})$ for $\mathrm{Pb}$, $\mathrm{Co}$ and $\mathrm{Cu}$ close to 1 can be considered to have terigeneous in sources. Generally, the concentration of $\mathrm{Pb}, \mathrm{Co}$ and $\mathrm{Cu}$ at present is not widespread enough as to have much influence on pollution of that area.
\end{abstract}

ABSTRAK 26 sedimen permukaan yang diperoleh dari lagun Setiu telah dianalisis bagi menentukan taburan kepekatan $\mathrm{Pb}$, $\mathrm{Co}$ dan $\mathrm{Cu}$ dengan menggunakan Inductively Coupled Plasma Mass Spectrometer (ICP-MS). Purata kepekatan $\mathrm{Pb}, \mathrm{Co}$ dan $\mathrm{Cu}$ di dalam sediment adalah masing-masing $23.26 \mu \mathrm{g} / \mathrm{g}$ berat $\mathrm{kering}$, $22.29 \mu \mathrm{g} / \mathrm{g}$ berat kering and $47.25 \mu \mathrm{g} / \mathrm{g}$ berat kering. Dalam kajian ini, nilai EF yang didapati menghampiri 1 dan boleh dianggap sebagai berasal dari sumber terigenus yang dominan. Secara keseluruhannya, kawasan kajian tidak tercemar dengan kepekatan $\mathrm{Pb}, \mathrm{Co}$ dan $\mathrm{Cu}$.

(Keywords: lagun Setiu, $\mathrm{Pb}, \mathrm{Co}, \mathrm{Cu}, \mathrm{EF}$ )

\section{INTRODUCTION}

Heavy metals are present in streams as a result of chemical leaching of bedrocks, water drainage and runoff from the banks and discharge of urban and industrial wastewaters [1]. Due to their strong affinity for sedimentary particle surfaces, scavenging by suspended particulate matter and subsequent sedimentation exacerbates the environmental impact of these pollutants and sustains the environmental deterioration of estuaries and neighboring coastal zone [2].

Setiu lagoon is a well known estuary in the northern part of Terengganu and is unique as it covers many ecosystems such as lagoon, rivers, sea, mangrove forest and small islands. The lagoon's ecosystem is semi-enclosed with limited and poor tidal flushings and has a total water surface area of about 880 ha. This study area is of primary oceanographic interest since it is one of the largest estuaries of the Terengganu coast into which two river systems flow, the Setiu river and Chalok river. These areas are an area of diverse ecosystem, with utilizable natural resources, a vast array of biological diversity and coastal and riverine fishing activities $[3,4]$.

For the comprehensive conservation and management plan of Setiu Lagoon, it is vital to determine the heavy metal concentration and organic carbon content in sediment as well as water parameters of Setiu Lagoon. Furthermore, there are limited information regarding to the geochemical profile of estuarine system in Malaysia and only some initial research had been done $[5,6]$. 


\section{METHODOLOGY}

\section{Site description and sampling}

Samples were collected from the Setiu Lagoon of Terengganu from 26 stations along the estuary (Figure 1). The bottom sediment samples were collected by using a Ponar Grab. All samples will be dried in oven at $60^{\circ} \mathrm{C}$ until constant weight and ground to a fine powder with a porcelain mortal and pestle. Precautions to prevent contamination are given a priority. Digestion and analytical procedures for all chemical elements will be analyzed using the published methods.

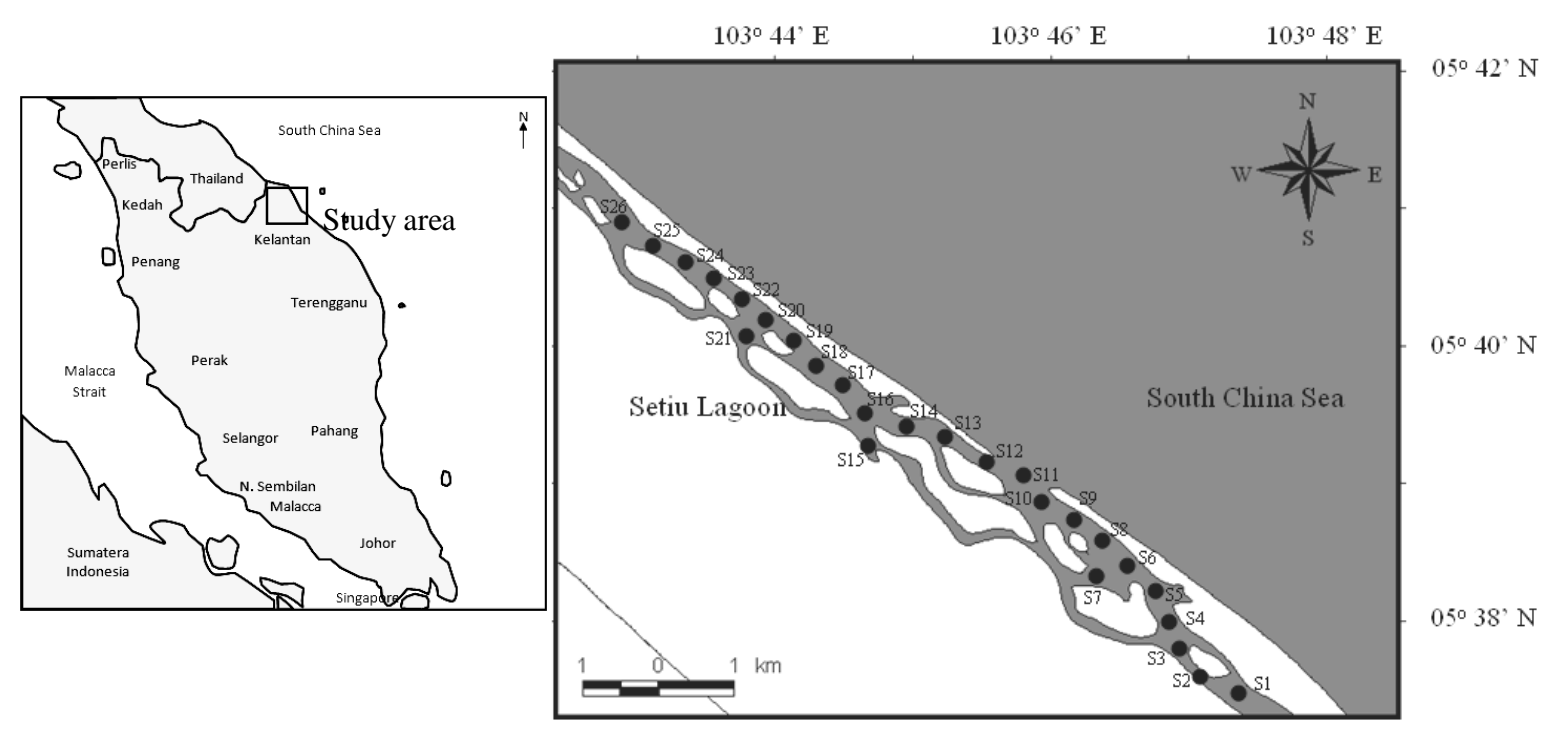

Figure 1. Location of study area showing the sampling site along Setiu Lagoon, Terengganu, Malaysia

\section{Heavy metal analysis}

The sediment samples were digested according to the published methods with some modifications $[7,8,9]$. An inductively-coupled plasma mass spectrometer (ICP-MS) was used for the quick and precise determinations of $\mathrm{Pb}, \mathrm{Cu}, \mathrm{Mn}$ and $\mathrm{Zn}$ in the digested marine sediment. Briefly, the digestion method involved the heating of $50 \mathrm{mg}$ of a $<63 \mu \mathrm{m}$ size sample in a sealed teflon vessel with a mixed concentrated acids of $\mathrm{HF}, \mathrm{HNO}_{3}$ and $\mathrm{HCl}$ in the ratio of 2.5: 3.5: 3.5. The teflon vessels were kept at $150{ }^{0} \mathrm{C}$ for 5 hours. After cooling, a mixed solution of boric acid and EDTA was added, and the vessel was again heated at 150 ${ }^{0} \mathrm{C}$ for 5 hours. After cooling to room temperature, the content of the vessel was thoroughly transferred into a $10 \mathrm{ml}$ polypropylene test tube and was diluted to $10 \mathrm{ml}$ with $5 \% \mathrm{HNO}_{3}$. A clear solution with no residue should be obtained at this stage. The precision assessed by replicate analyses was within 3\%. The accuracy was also examined by analyzing, in duplicate a
Canadian Certified Reference Materials Project standard (DL-1a) and the results coincided with the certified values within a difference of $\pm 3 \%$.

\section{RESULTS AND DISCUSSIONS}

The distributions of $\mathrm{Pb}, \mathrm{Co}$ and $\mathrm{Cu}$ concentration at Setiu Lagoon are given in the bar graph (Figure 2). Generally, the results indicate that the concentration of $\mathrm{Pb}, \mathrm{Co}$ and $\mathrm{Cu}$ were higher than the average concentrations estimated for shales and mean crustal materials $[10,11]$. For $\mathrm{Pb}$ concentration, the average concentration was $23.36 \mu \mathrm{g} / \mathrm{g}$ dry weights, ranged from $10.58 \mu \mathrm{g} / \mathrm{g}$ dry weight to $45.22 \mu \mathrm{g} / \mathrm{g}$ dry weights. The concentrations of Co with sampling points was varied from $8.54 \mu \mathrm{g} / \mathrm{g}$ dry weight to $32.29 \mu \mathrm{g} / \mathrm{g}$ dry weight, average at $22.29 \mu \mathrm{g} / \mathrm{g}$ dry weight. The average concentration of $\mathrm{Cu}$ ranged from 9.12 $\mu \mathrm{g} / \mathrm{g}$ dry weights to $94.40 \mu \mathrm{g} / \mathrm{g}$ dry weight, average at $47.25 \mu \mathrm{g} / \mathrm{g}$ dry weights. The contribution of these metals in the study area would likely be due to the anthropogenic activities 
such as boating, sand mining [5], and sea dumping activities. Furthermore, the elevation of river discharge resulted from a combination of factors including industrial discharges to the river, inputs from weathering and the effects of local activities nearby are likely contributes to $\mathrm{Pb}, \mathrm{Co}$ and $\mathrm{Cu}$ concentration throughout the study area.

Table 1. $\mathrm{Pb}, \mathrm{Co}$ and $\mathrm{Cu}(\mu \mathrm{g} / \mathrm{g}$ dry weights) distribution at Setiu Lagoon, Terengganu

\begin{tabular}{|c|c|c|c|}
\hline Station & $\begin{array}{c}\mathrm{Pb} \\
(\mu \mathrm{g} / \mathrm{g} \text { dry weights) }\end{array}$ & $\begin{array}{c}\text { Co } \\
(\mu \mathrm{g} / \mathrm{g} \text { dry weights) }\end{array}$ & $\begin{array}{c}\mathrm{Cu} \\
(\mu \mathrm{g} / \mathrm{g} \text { dry weights })\end{array}$ \\
\hline S1 & 13.80 & 13.99 & 46.78 \\
\hline S2 & 14.69 & 25.02 & 38.77 \\
\hline S3 & 19.21 & 25.83 & 34.51 \\
\hline S4 & 10.68 & 28.87 & 39.72 \\
\hline S5 & 14.90 & 8.54 & 20.43 \\
\hline S6 & 19.34 & 8.77 & 94.40 \\
\hline S7 & 14.90 & 18.28 & 36.76 \\
\hline S8 & 15.89 & 26.65 & 29.87 \\
\hline S9 & 16.58 & 27.24 & 45.79 \\
\hline S10 & 22.94 & 13.10 & 31.45 \\
\hline S11 & 27.50 & 27.44 & 19.89 \\
\hline S12 & 19.24 & 17.74 & 62.27 \\
\hline S13 & 29.40 & 27.45 & 66.41 \\
\hline S14 & 30.34 & 31.57 & 59.81 \\
\hline S15 & 45.22 & 29.46 & 21.63 \\
\hline S16 & 27.82 & 15.41 & 47.81 \\
\hline S17 & 11.98 & 11.95 & 89.28 \\
\hline S18 & 23.62 & 29.04 & 72.55 \\
\hline S19 & 30.72 & 32.29 & 61.08 \\
\hline S20 & 23.38 & 30.32 & 63.66 \\
\hline S21 & 30.26 & 22.24 & 9.12 \\
\hline S22 & 32.16 & 14.62 & 60.57 \\
\hline S23 & 25.03 & 29.15 & 66.25 \\
\hline S24 & 35.16 & 32.08 & 55.88 \\
\hline S25 & 28.32 & 13.89 & 22.08 \\
\hline S26 & 22.25 & 18.72 & 31.77 \\
\hline Average & 23.28 & 22.29 & 47.25 \\
\hline $\begin{array}{l}\text { Mean crustal } \\
\text { materials }\end{array}$ & 20 & 19 & 45 \\
\hline
\end{tabular}



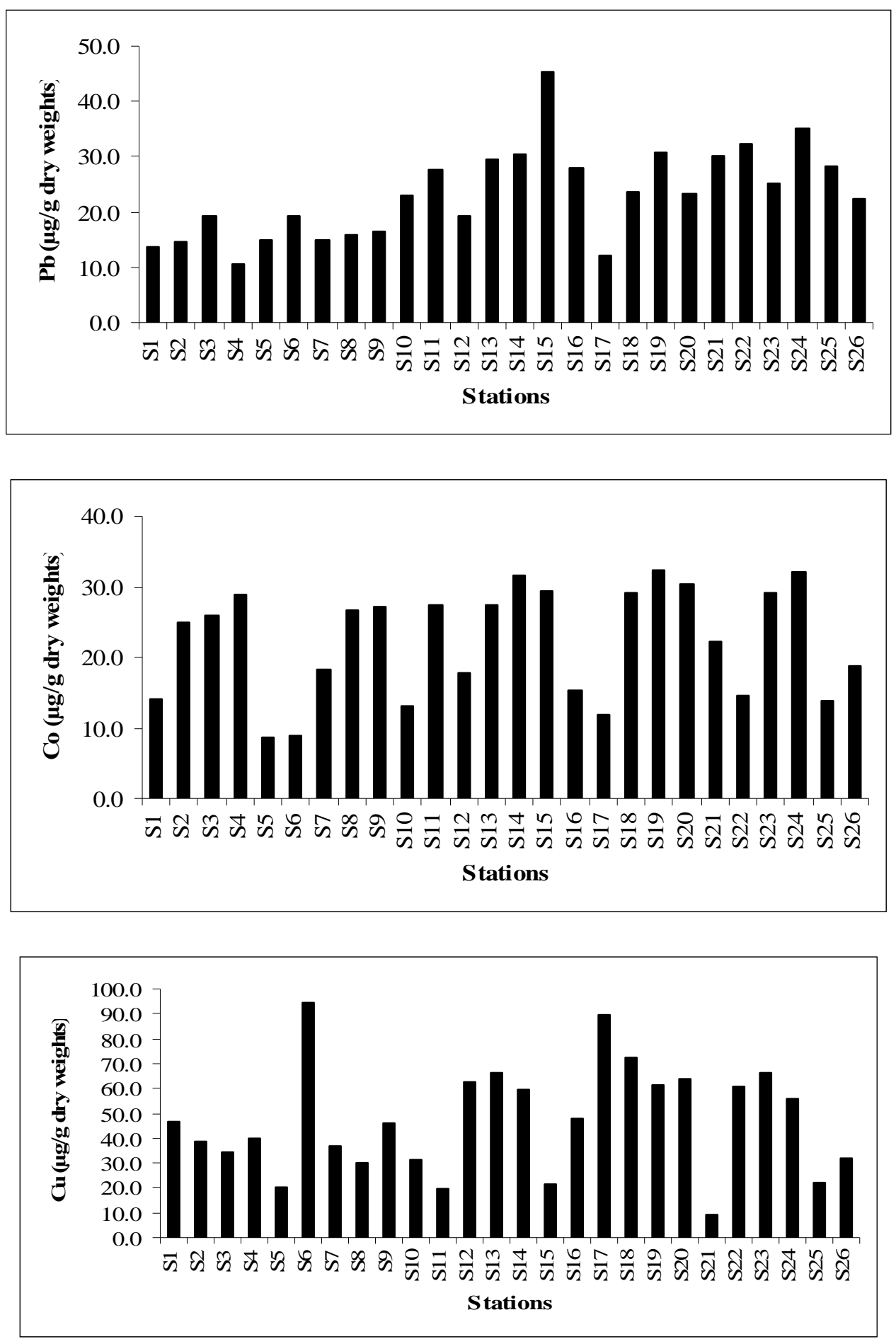

Figure 2. $\mathrm{Pb}, \mathrm{Co}$ and $\mathrm{Cu}(\mu \mathrm{g} / \mathrm{g}$ dry weights) distribution at Setiu Lagoon, Terengganu 
Anthropogenic activities had caused important transformation in coastal environments during the last 150 years. Heavy metals were among the most widespread of the various pollutants originating from anthropogenic activities, particularly from mining and smelting waste sites $[12,13]$. The approach most often used to determine the sources of the pollutant is through the normalization of geochemical data to reference metal. The reference metal must therefore be an important constituent of one or more of the major fine-grained trace metal carriers reflect their granular variability in the sediment. The most often used reference metal is $\mathrm{Al}$, which represents a chemical tracer of Al-silicates, particularly the clay minerals $[14,15,16]$. For a better estimation of anthropogenic input, an enrichment factor was calculated for each metal by dividing its ration to the normalizing element by the same ration found in the chosen baseline. EF values are applied to evaluate the dominant source of the sediments and as indicators for pollution [17] and describe as:

$$
\mathrm{EF}=(\mathrm{E} / \mathrm{Al})_{\text {sed }} /(\mathrm{E} / \mathrm{Al})_{\text {crust }}
$$

where $(\mathrm{E} / \mathrm{Al})_{\text {sed }}$ and $(\mathrm{E} / \mathrm{Al})_{\text {crust }}$ are the relative concentrations of the respective element $\mathrm{E}$ and $\mathrm{Al}$ in the sediment and in the crustal material, respectively [10, 11, 18, 19]. An enrichment factor close to 1 would indicate a crustal origin, while those with factors greater than 10 are considered to have non-crustal sources. From the average calculated value for $\mathrm{Pb}, \mathrm{Co}$ and $\mathrm{Cu}$ was 0.91 (0.70-1.12), 0.91 (0.64-1.04) and 0.89 (0.52$1.08)$, respectively, it is clear that all elements has EF values close to unity and may therefore be considered to be predominantly terrigenous in origin.

\section{CONCLUSION}

Generally metals concentrations in the sediment were much influenced by the natural processes and show some relative enrichment near the estuary compared to upstream. The calculated EF for all elements indicates their occurrence in both lithogenous and non-lithogenous fractions. In conclusion, even though the Setiu estuary and nearby areas are rapidly developing, the activities at present are not widespread enough as to have much influence on pollution of the area.

\section{ACKNOWLEDGEMENTS}

This research was conducted with joint funding from the Malaysia Ministry of Science Technology and Innovation under the Intensified Research for Priority Areas (IRPA). The authors wish to express their gratitude to Oceanography Laboratory and INOCEM team for their invaluable assistance and hospitality throughout the sampling period.

\section{REFERENCES}

1. Soares H.M.V., Boaventura R., Machado A.A.S.C. and Silva J.C.G. (1999). Sediments as Monitors of Heavy Metal Contamination in the Ave river basin (Portugal): Multivariate Analysis of Data. Environment Pollution 105: 311 - 323.

2. Gerritse R.G., Wallbrink P.J. and Murria A.S. (1998). Accumulation of Phosphorus and Heavy Metals in the Swan-Canning Estuary, Western Australia. Estuaries, Coastal, Shelf Science 47: 165 - 170.

3. Ong, M.C. (2006). Geochemistry of Sediment and heavy Metals in the Major Estuarine Mangrove Forest of Terengganu, Malaysia. Master of Science Thesis. Submitted to Kolej Universiti Sains \& Teknologi Malaysia. 225p.

4. Kamaruzzaman B.Y., Effendy A.W.M., Ahmad Shamsuddin A. and Nor Afandy B.H. (2005). Vertical and Horizontal Variability of Organic Carbon in Setiu Mangrove Forests, Malaysia. Chemical Research Communication 18: 33 - 37.

5. Kamaruzzaman B.Y., Husain M.L., Shazili N.A.M., Sulong, I. and Rashid, K.A. (2002). Study on the Distribution of Some Heavy Metals and Pollution Status of a Tropical Microtidal River: The Chukai-Kemaman River, Terengganu, Malaysia, Dimensions of Pollution 1: 115 - 130.

6. Noor Azhar M.S., Kamaruzzaman B.Y., Rosnan Y. and Nor Antonina A. (2003) Speciation of $\mathrm{Cu}, \mathrm{Pb}$ and $\mathrm{Zn}$ in Sediments of Ibai Estuary, Kuala Terengganu, Malaysia. Dimensions of Pollution 2: 43-52.

7. Noriki, S.K., Nakanishi, T., Fukawa, M., Uematsu, T., Uchida and S. Tsunogai (1980). Use of a Teflon Vessel for the Decomposition Followed by the Determination of Chemical 
Contituents of Various Marine Samples. Bull. Fac. Fish, Hokkaido Univ., 31: 354 465.

8. Sen Gupta J.G. and Bertrand N.B. (1995). Direct ICP-MS determination of trace and ultratrace elements in geological materials after decomposition in a microwave oven, Quantitation of Y, Th, U and lanthanides. Talanta, 42: 1595-1607.

9. Kamaruzzaman B.Y. (1999). Geochemistry or the Marine Sediments. Its Paleoceanographic Significance. Ph.D Thesis. Submitted to Hokkaido University. 143p.

10. Turekian K.K. and Wadepohl D.H. (1961). Distribution of the Elements in Some Major Units of the Earth's Crust. Bull. Geol. Soc. Amer. 72: 175 - 192.

11. Wadepohl K.H. (1995). The Composition of the Continental Crust. Geochim. Cosmo. Acta 95: 1217 - 1232.

12. Solomons W. (1995). Environmental impact of metals derived from mining activities: Processes predictions, prevention. Journal of Geochemical Exploration 52: 5-23.

13. Hochella Jr., M.F., Moor J.N., Golla U. and Putnis A. (1999). A TEM study of samples from acid mine drainage systems: Metalmineral association with implication for transport. Geochimica at Cosmochimica Acta 19-20: 3395-3406.

14. Din Z.B. (1992). Use of aluminium to normalize heavy metal data from estuarine and coastal sediments of Straits of Melaka. Marine Pollution Bulletin 24: 484-491.

15. Weijden V.C.H. (2002). Pitfalls of normalization of marine geochemical data using a common divisor. Marine Geology 184: $167-187$.

16. Loring D.H. and Rantala R.T.T. (1992). Manual for the geochemical analyses of marine sediments and suspended particulate matter. Earth Sciences Review 32: 235-283.

17. Taylor S.R. (1964). Abundance of chemical elements in the continental crust: a new table. Geochimica et Cosmochimica Acta 28: 1273 -1285 .

18. Molinari E., Guerzoni S. and Rampazzo G. (1993). Contribution of Saharan Dust to the Central Mediterranean Basin. Geological Society of America, special paper 284: 303 312.
19. Kremling K. and Streu P. (1993). Saharan dust influence trace element fluxes in deep North Atlantic subtropical waters. Deep Sea Research 40: 1155 - 1168. 